Original Article

\title{
The bioprotective role of irradiated hibiscus against harmful effects of using repeatedly frying edible oil
}

\author{
O papel bioprotetor do hibisco irradiado contra os efeitos nocivos do uso de óleo \\ comestivel para fritar
}

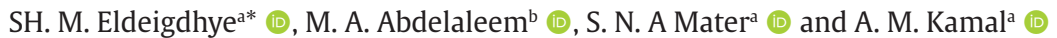 \\ aEgyptian Atomic Energy Authority, Nuclear Research Center, Biological Applications Department, Cairo, Egypt \\ ${ }^{\mathrm{b} E g y p t i a n}$ Atomic Energy Authority, Nuclear Research Center, Plant Research Department, Cairo, Egypt
}

\begin{abstract}
Repeatedly frying process of dietary edible oil has a potential role in the generation of free radicals. Therefore, questions have always been raised as to whether, there is an efficient and economical method to reduce the harmful effects of repeated use of frying edible oil. Since hibiscus has been stated to have a wide variety of therapeutic effects, it was important to investigate its properties against harmful effects of free radicals. The current study aspires to find out whether irradiated powder of hibiscus has a protective role against adverse effects of repeated use of frying edible oil. Thirty-five adult male albino rats were equally assigned into five groups. First group"G1" was fed with normal diet as control group, meanwhile, group"G2" the diet mixed with fresh oil, "G3" diet mixed with repeatedly frying oil only, "G4" diet mixed with frying oil treated with hibiscus and "G5" diet mixed with frying oil treated with irradiated hibiscus. Feeding duration was six weeks. Fatty acid analyses of oil as well as peroxide values were determined. Blood and liver samples were collected for biochemical analyses as well as histological study. Repeatedly heated cooked oil has significant increases in peroxide value, acid value, free fatty acid and both conjugated diene and triene compared with repeatedly frying oil treated with hibiscus. Also there are significant increases in cholesterol and triglyceride and impaired in liver functions in "G3"compared with others. In addition, relative to the hibiscus groups, there is a substantial reduction in oxygen consumption in "G3". Both hibiscus as well as irradiated hibiscus attract attention in order to play a vital and economical role against harmful effects of frequent use of frying edible oil on some biological functions but, irradiated hibiscus was more effective.

Keywords: frying oil, irradiated hibiscus, liver functions, oxygen consumption assays, lipid profile, peroxide value, free fatty acid, acid value.
\end{abstract}

\begin{abstract}
Resumo
O processo de fritura repetida de óleo comestível da dieta tem papel potencial na geração de radicais livres que podem ter efeitos prejudiciais em algumas funções biológicas. Portanto, sempre se questionou se existe uma maneira eficiente e econômica de prevenir ou pelo menos reduzir os efeitos nocivos do uso repetido de óleo comestível para fritar. Como o hibisco tem ampla variedade de efeitos terapêuticos, foi importante investigar suas propriedades como agente antioxidante contra os efeitos nocivos dos radicais livres. 0 presente estudo pretende descobrir se 0 pó irradiado de hibisco tem papel protetor contra os efeitos adversos do uso repetido de óleo comestível para fritar. Trinta e cinco ratos albinos machos adultos foram divididos igualmente em cinco grupos. O primeiro grupo "G1" foi alimentado com dieta normal como grupo controle, enquanto o grupo "G2" dieta misturada com óleo fresco, dieta "G3" misturada com óleo de fritura repetida, dieta "G4" misturada com óleo de fritura tratada com hibisco e dieta "G5" misturada com óleo de fritura tratada com hibisco irradiado. A duração da alimentação foi de seis semanas. Foram determinadas as análises de ácidos graxos de óleo, bem como os valores de peróxidos. Amostras de sangue e fígado foram coletadas para análises bioquímicas e estudo histológico. O óleo cozido repetidamente aquecido tem aumentos significativos no valor de peróxido, valor de ácido, ácido graxo livre e dieno e trieno conjugados em comparação com óleo de fritura repetidamente tratado com hibisco. Também há aumentos significativos no colesterol e triglicérides e comprometimento das funções hepáticas no "G3" em comparação com outros. Além disso, em relação aos grupos de hibiscos, há uma redução substancial no consumo de oxigênio no "G3". Tanto o hibisco como o hibisco irradiado chamam atenção por desempenhar papel vital e econômico contra os efeitos nocivos do uso frequente de óleo comestível para fritar em algumas funções biológicas, mas o hibisco irradiado foi mais eficaz.
\end{abstract}

Palavras-chave: óleo de fritura, hibisco irradiado, funções do fígado, ensaios de consumo de oxigênio, perfil lipídico, índice de peróxido, ácido graxo livre, índice de ácido.

*e-mail: shaimaa122019@yahoo.com

Received: June 8, 2021 - Accepted: August 12, 2021

This is an Open Access article distributed under the terms of the Creative Commons Attribution License, which permits unrestricted use, distribution, and reproduction in any medium, provided the original work is properly cited. 


\section{Introduction}

Edible oils are one of the most important dietary ingredients in everyday food consumption, and they're used in almost every form of food preparation, including baking frying and extrusion cooking. They're usually made from oil seeds (i.e. sunflower, mustard, and cotton seed). Deep frying with vegetable oils is one of the most popular food preparation methods all over the world. In an effort to save money, it's also popular to reuse oils for multiple frying sessions. As oils are heated to between 170 and 220 degrees Celsius for frying, they undergo physicochemical changes such as oxidation, hydrolysis, cyclization, and polymerization as well as gradually degrade to volatile compounds (Ku et al., 2014). Which makes it much more dangerous when these oils are consumed together. Many experiments have shown that reheated oils have genotoxic (Dung et al., 2006), mutagenic and carcinogenic potential (Srivastava et al., 2010a, b).

Therefore it was important to place emphasis on uncovering natural products that may be useful in reducing the harmful effects of reheated edible oils and with very little side effect. As, Plant products seem to play a key role against oxidative stress due to the presence of antioxidant principles such as alkaloids, flavonoids and phenolic acids (Chirag et al., 2014).

Hibiscus (roselle), a member of the Malvaceae family, is cultivated in Egypt for a variety of medicinal purposes. It is known in Egypt as "Karkadeh," and its purplish sepals (calyx and epicalyx) are the most important economic parts of the plant, which are used as a source of natural colouring agent in food (jam and jelly) and cosmetic industries (El-Meleigy, 1989).

According to Kalt et al. (1992), the pigments (anthocyanin) that are mainly responsible for red colour are delphinidin 3 glucoside and cyanidin-3 glucoside. It also has a beneficial effect on stomach functions. It has a strong antiseptic action in the intestine and can be used to fight infections in the intestine, as well as to fight cancer, diabetes, obesity, and microbes, in addition to a neuroprotective agent (Khoo et al., 2017). Protocatechuic acid (a basic phenolic compound) found in Hibiscus sabdariffa, according to Tanaka et al. (1993), may be used to treat pyrexia and liver disorders.

Furthermore, this compound (anthocyanin) has been shown to be an important agent in reducing the carcinogenic effects of diethylnitrosamine in the liver (Raifa et al., 2005). This plant has been found to contain phenolic compounds, anthocyanins, flavonols, and protocatechuic acid (PCA) in previous phytochemical studies (Seca et al., 2001a, b). It is a well-known fact that most medicinal plants are high in phenolic compounds and bioflavonoids, both of which have strong antioxidant properties (Shirwaikar et al., 2003). However, although there have been numerous studies on the phytochemical constituents and various medicinal activities attributed to this plant, no biochemical or histological studies have been performed to shed light on the role of Hibiscus in protecting experimental rats' liver functions from the harmful effects of repeatedly frying oil.
Since then, gamma irradiation has proven to be an effective tool for reducing microbial load, preserving product quality and protection, and extending the shelf life of natural products (Mun'im et al., 2017). There are also some studies that demonstrate how gamma irradiation affects total phenolic content (TPC) and total flavonoid content (TFC). Furthermore, gamma irradiation increased TPC in clove, nutmeg, and almond skin after irradiation (Harrison and Were, 2007). This increasing may be attributed to the breakdown of tannins into a simple phenol compound, which led to the overall phenolic content increasing (Soriani et al., 2005)

In view of the above, the current research was carried out to investigate the bioprotective effects of hibiscus as well as irradiated hibiscus against both in vitro (peroxide value, acid value, free fatty acid, colour and both conjugated diene and triene) as well as in vivo (liver functions, lipid profile, oxygen consumption and histology studies) harmful effects of repeatedly frying oil.

\section{Materials and Methods}

\subsection{Materials}

Mature dry dark-red calyces of Hibiscus were purchased from a local market in Cairo, Egypt and, Sunflower oil (SFO) were purchased from Arma for food industry Company. $10^{\text {th }}$ of Ramadan, Cairo, Egypt. All biochemical kits including lipid profile [triglycerides (TG), total cholesterol (TC), high density lipoprotein (HDL), low density lipoprotein (LDL) and very low density lipoprotein (VLDL)] as well as, liver functions [alanine aminotransferase (ALT) and aspartate aminotransferase (AST)], albumin, bilirubin and total protein were purchased from Linear Chemicals, S.L.U., Barcelona, Spain.

\subsection{Methods}

\subsubsection{Irradiation treatments}

Fine powder of hibiscus herb were irradiated with gamma irradiation at doses of 1.5 and $3 \mathrm{KGy}$ using an experimental ${ }^{60} \mathrm{Co}$ gamma chamber (dose rate $665.6 \mathrm{~Gy} / \mathrm{h}$ ), Cyclotron project, nuclear research center, Egyptian atomic energy authority, Egypt.

\subsubsection{Oxidative stability measured as induction period by Rancimat}

According to the method defined by Mendez et al. (1996), the oxidative stability of sunflower oil was calculated using an automated Rancimat (Metrohm Ltd. CH-9100 Herisau, Switzel and, model 679), which consists of the control unit and the wet section containing 6 reaction vessels.

\subsubsection{Proximate physicochemical analyses of sunflower oils}

Acid value, fatty acid (oleic acid \%) and peroxide value were determined according to standard IUPAC methods for the analysis of oils and fats (Dieffenbacher and Pocklington, 1987). While, refractive index of the oils measured according to method of AOAC (2005). 


\subsubsection{Experimental animals}

Thirty five adult male albino rats weighing between $160-180 \mathrm{~g}$ were used in this study. Animals were allowed for acclimatization 2 weeks under standard laboratory conditions, i.e.; room temperature of $28 \pm 2{ }^{\circ} \mathrm{C}$, and a $12: 12 \mathrm{~h}$ dark / light cycle. The Research Ethics Committee of the National Center for Radiation Research and Technology, Atomic Energy Authority Egypt, approved the experimental protocol with serial number $7 \mathrm{~A} / 21$ for the purpose of monitoring and supervising experimental animals.

\subsection{Experimental designs}

\subsubsection{In vitro designs (physicochemical study)}

Fresh sunflower oil samples underwent 3 different treatments, which includes (1), using fresh oil for repeatedly frying ( 8 times) for potatoes ( 4 times) as well as falafel (4 times) at temp. (170-220 $\left.{ }^{\circ} \mathrm{C}\right)$. The (2), fresh sunflower oil which contains hibiscus powder) in specific bowl of gauze) used for frying ( 8 times) for potatoes (4 times) as well as falafel (4 times), then (Soaking) with hibiscus for $120 \mathrm{hr}$. The (3), fresh sun flower oil which contains irradiated hibiscus powder) in specific bowl of gauze) used for frying ( 8 times) for potatoes ( 4 times) as well as falafel ( 4 times) at temp. $\left(170-22^{\circ} \mathrm{C}\right)$, then (Soaking) with irradiated hibiscus for $120 \mathrm{hr}$., after that all samples of oils were underwent analysis that were mentioned above.

\subsubsection{In vivo designs (biochemical study)}

The rats were divided into five groups with seven rats per group. Group (1) negative control group, healthy and untreated rats served as a normal control and maintained on regular rat diet and water only, Group (2) rats were fed on diet mixed with non-treated and non-fried (fresh) sunflower oil (7\% w|w), Group (3) rats were fed on diet mixed with repeatedly (8 times) frying sunflower oil $(7 \% w \mid w)$, Group (4) rats fed on regular diet mixed with repeatedly (8 times) frying oil $(7 \% \mathrm{w} \mid \mathrm{w})$ which, treated with hibiscus powder (Soaking) for $120 \mathrm{~h}$, and Group (5) rats fed on regular diet mixed with repeatedly (8 times) frying oil $(7 \% \mathrm{w} \mid \mathrm{w})$ which, treated with irradiated ( $1.5 \mathrm{kGy})$ hibiscus powder (Soaking) for $120 \mathrm{~h}$. Rats were fed for 6 weeks, then, rats were sacrificed and blood samples as well as liver tissue were taken for biochemical analysis and histological studies.

\subsection{Samples collection}

\subsubsection{Blood sampling}

Blood samples were taken at the end of the experiment (6 weeks) for biochemical analyses (Schermer, 1967; Dhandapani et al., 2002).

\subsubsection{Biochemical analyses}

Serum levels of triglyceride (TG), total cholesterol (TC), low density lipoproteins (LDL), high density lipoprotein (HDL), Alanine transaminase (ALT), Aspartate transaminase (AST), bilirubin, total protein and albumin, all parameters were evaluated according to Bio-Kinetic methods manufacturer's instructions of Linear Chemicals, S.L.U., Barcelona, Spain.

\subsubsection{Tissue sampling}

Rats were sacrificed by decapitation, the liver specimen quickly removed and washed for (biochemical analysis, mitochondria isolation and histopathological studies).

\subsection{Oxygen consumption assays}

\subsubsection{Mitochondrial isolation from liver (rats)}

According to Murphy (2012), liver was placed in liver isolation buffer (LIB) and cut slowly in little pieces with a scissor, pieces were washed as many times with LIB to remove all blood, liver pieces were homogenized in a PotterElvehjem with $60 \mathrm{~mL}$ LIB and maintain temperature under $4{ }^{\circ} \mathrm{C}$, the homogenate liver were centrifuged at 2,000 $\times \mathrm{g}$ during $10 \mathrm{~min}$ (Sorvall RC6 plus centrifuge; SS-34 rotor)., supernatant was poured to new refrigerated centrifuge tubes, and fill up with LIB. Avoid contamination with debris from pellet, the supernatant was centrifuge at 12,000 $\times$ g during $10 \mathrm{~min}$. , the new supernatant was discharged, and gently homogenize pellet with a smooth paintbrush, adding liver re-suspension buffer (LRB), supernatant was discharged and re-suspend isolated mitochondria in 200$300 \mathrm{~mL}$ in LRB and finally, store mitochondria on ice until start oxygen respiration assays.

\subsubsection{Liver mitochondria respiration medium}

Respiratory measurements of mitochondria were performed in $3.5 \mathrm{~mL}$ of air-saturated medium with $5 \mathrm{mM}$ succinate, $2 \mathrm{mM} \mathrm{MgCl} 2,2 \mathrm{mM} \mathrm{H} 3 \mathrm{PO} 4,2$ mM EGTA, $30 \mathrm{mM}$ HEPES, $0.1 \%$ BSA, pH 7.4, at $24{ }^{\circ} \mathrm{C}$. Oxygen consumption was determined using a Clark-type oxygen electrode (Rank Brothers Ltd., Cambridge, England). Data are expressed as the respiratory control $(\mathrm{RC})$ ratio that indicates the respiratory coupling in availability of ADP according to Poe et al. (1967).

\subsection{Biochemical analysis in liver tissues}

The liver tissues were minced into small pieces homogenized in phosphate buffer ( $\mathrm{pH} 7.4)$, the homogenates were centrifuged for 15 minute, and then the supernatants were used for biochemical analysis (lipid profile and liver functions).

\subsection{Histopathological study}

To emphasize the presence of liver damages, rats were sacrificed and their livers were isolated and used for histopathological studies. The livers were washed and after that fixed with $10 \%$ formalin ( $\mathrm{pH} 7.4$ ), then soaked in paraffin, cut at $5 \mu \mathrm{m}$ intervals and the slides were stained with hematoxylin and eosin stains. Slides of tissue were photographed using optical microscopy and observed the pathological changes, then images were taken at (H\&E X200) (Culling, 1983). 


\subsection{Statistical analysis}

Data of the present study were statistically evaluated by use of one-way ANOVA, followed by post hoc Duncan's test using version 16 of SPSS software. The values were considered significant when $\mathrm{P}<0.05$ (Levesque, 2007).

\section{Results}

\subsection{Physicochemical analyses on sunflower oil}

Physical and chemical parameters of fried sunflower oil both treated and non-treated with hibiscus powder are summarized in Table 1 . Refractive index show non-significant differences $(\mathrm{P}>0.05)$ in all treated and non-treated samples, as well as yellowish color which is fixed at 35, while reddish color increase significantly ( $P>$ 0.05 ) in fried oil treated with hibiscus power. Acid value of sunflower oils was increased significantly ( $P>0.05$ ) during repeatedly frying where it is $2.03 \mathrm{mg} \mathrm{KOH} / \mathrm{g}$ Oil, while it decrease significantly $(\mathrm{P}>0.05)$ due to adding both irradiated and non-irradiated hibiscus powder. Free fatty acid values, expressed as \% of oleic acid, varied between 0.66 and $1.92 \%$ oleic. The highest free acid amount is obtained from non-treated frying oil. The oil treated with irradiated hibiscus represent significantly decreased in the percentage of oleic fatty acid. The absorbance $(\lambda)$ measured at 232 and $270 \mathrm{~nm}$ was used to evaluate the formation of conjugated dienes and trienes. The values of conjugated dienes and trienes are shown in Table 1. In both control or non-fried/non-treated oil and frying oil treated with irradiated hibiscus represent the lowest conjugated dienes values 5.78 and $6.45 \mu \mathrm{mol} / \mathrm{g}$, respectively. While, it is showed that highest significant $(P>0.05)$ value in frying oil without any treatment. In the conjugated trienes, all treated oils possess significantly $(P>0.05)$ increasing compared to control or non-frying oil.

The peroxide value varied between 2.46 and $23.17 \mathrm{meq}$ $\mathrm{O}_{2} / \mathrm{kg}$ oil, indicating that the tested treated oils are ranged from non-deteriorated oil to rancid one. The peroxide value of frying oil is 23.17 meq $\mathrm{O}_{2} / \mathrm{kg}$ oil while it decreased significantly $(\mathrm{P}>0.05)$ to 14.49 meq $\mathrm{O}_{2} / \mathrm{kg}$ oil in frying oil treated with irradiated hibiscus powder. The oxidative stability of sunflower oil measured as induction stability at $110{ }^{\circ} \mathrm{C} / \mathrm{h}$, shown in Table 1 show that the induction period of control sunflower oil is $6.35 \mathrm{~h}$ while, it decrease significantly $(\mathrm{P}>0.05)$ in non-treated frying oil. However, in frying oil treated with hibiscus powder and then immersed with hibiscus powder is $7.03 \mathrm{~h}$.

\subsection{Effect of repeatedly frying oil on lipid profile}

This study showed that, there are highly significant increases in (cholesterol, triglyceride, LDL and VLDL), on the other hand there are significant decrease in HDL in the level of both liver tissue as well as serum in "G3", compared with "G1" and "G2". Meanwhile hibiscus groups"G4" and "G5" showed significant decreases in (cholesterol, triglyceride, LDL and VLDL) as well as significant increases in HDL compared with "G3" as shown in Table 2.

\subsection{Effect of repeatedly frying oil on oxygen consumption}

The current study showed that, repeatedly frying oil has significant decreases in oxygen consumption of liver mitochondria in "G3" compared with "G1" and "G2" as $(\mathbf{1 0 . 6 3} \pm \mathbf{0 . 8}, \mathbf{1 3 . 0 6} \pm \mathbf{1}$ and $\mathbf{1 2 . 9 3 \pm 0 . 5 )}$ respectively. In the contrary, both "G3" and "G4" showed significant increases in oxygen consumption compared with "G3" but in case of "G4" it was highly significant increases by $(\mathbf{1 7} \pm \mathbf{1 . 5})$ as shown in Figure 1.

\subsection{Effect of repeatedly frying oil on liver functions}

Data of present study postulated that harmful effects of repeatedly frying oil on repertory of mitochondria had adverse impacts on liver function in both the level of liver tissue as well as serum which is investigated in Table 3. As, there are significant increasing in level of (ALT, AST) in "G3", compared with normal group "G1" and "G2". Moreover, there is significant decrease in total protein in "G3" compared with normal control group. While, there are significant decrease in liver enzymes (ALT, AST) in "G4" and "G5" groups compared with frying oil group "G3". In addition, there was significant increase in total protein in both "G4" and "G5" compared with "G3", as shown in table. Overcome the protective effects against adverse effects of repeatedly frying oil were more evident in irradiated hibiscus other than hibiscus

\subsection{Effect of repeatedly frying oil on histological study of liver tissues}

It was important to investigate the extent of liver tissue damages. Therefore, histological examinations of liver tissues with (Hematoxylin and Eosin) stains were done, in the different studied groups, which, confirmed the biochemical studies in all studied groups, as shown in Figure 2. Normal group, "A", and "B" Liver from "G1" and "G2" respectively, showing normal hepatic parenchyma; note the normal central vein, hepatocytes, and blood sinusoids. While in "C", frying oil group"G3" showing congestion in the central vein (arrow head), Swelling degeneration of some hepatocytes (arrows) with focal areas of necrotic hepatocytes. Whereas, In both "D" as well as,

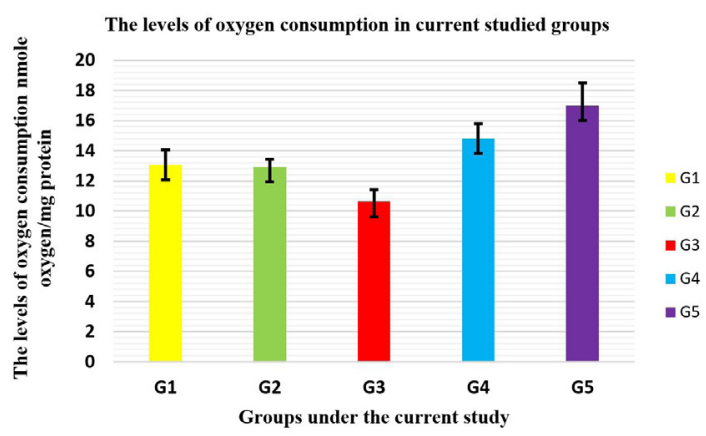

Figure 1. Showing the levels of oxygen consumption in studied groups, there are significant decreases in oxygen consumption in frying oil group "G3" compared with all groups, while there are significant increases in oxygen consumption in hibiscus groups "G4 and G5" compared with "G3". 


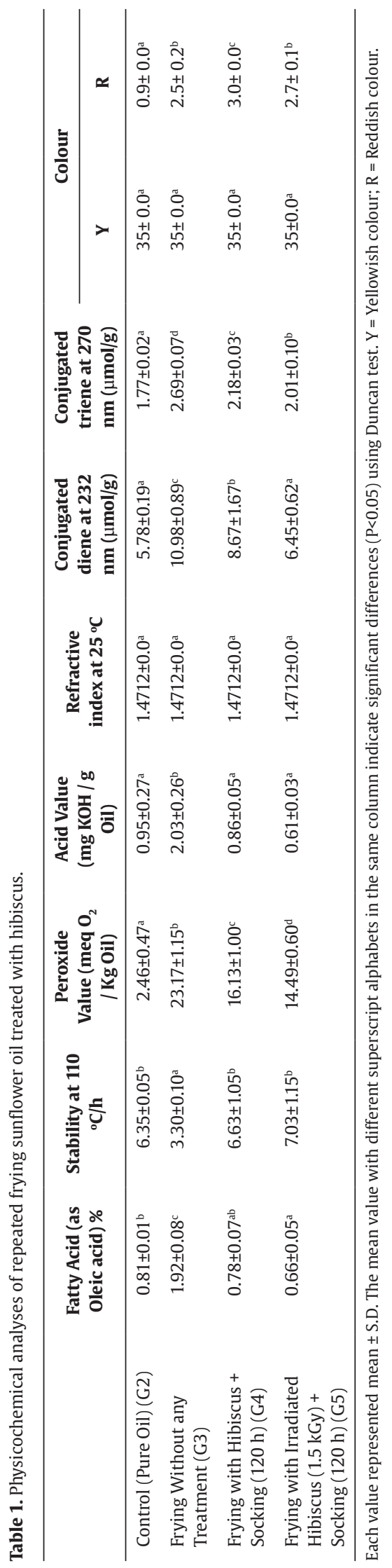


Table 2. Effects of different treatments on lipid profiles in both liver tissue as well as serum of all groups.

\begin{tabular}{|c|c|c|c|c|c|c|}
\hline & & Cholesterol & Triglyceride & HDL & LDL & VLDL \\
\hline \multirow{5}{*}{$\begin{array}{l}\text { In Tissue } \\
\text { (mg/g) } \\
\text { Groups }\end{array}$} & “G1” & $51 \pm 50$ & $44 \pm 20$ & $37 \pm 1.50$ & $5 \pm 0.85$ & $8 \pm 0.89$ \\
\hline & “G2” & $71 \pm 60^{\# \#}$ & $52 \pm 30^{\# \#}$ & $35 \pm 2.70$ & $14 \pm 1.20^{\# \#}$ & $10 \pm 1.70$ \\
\hline & “G3” & $111 \pm 7^{\# \# \# ~}$ & $121 \pm 8^{\# \# \#}$ & $29 \pm 1.5^{\#}$ & $24 \pm 3^{\# \# \#}$ & $27 \pm 2.3^{\# \#}$ \\
\hline & “G4” & $62 \pm 4^{* *}$ & $65 \pm 2^{* * *}$ & $33 \pm 0.5^{*}$ & $12 \pm 1.3^{* *}$ & $13 \pm 1.3^{* *}$ \\
\hline & “G5” & $47 \pm 5^{* * *}$ & $50 \pm 3^{* * *}$ & $35 \pm 1.8^{* *}$ & $6 \pm 0.57^{* * *}$ & $10 \pm 1.4^{* *}$ \\
\hline \multirow{5}{*}{$\begin{array}{l}\text { In Serum } \\
\text { (mg/dl) } \\
\text { Groups }\end{array}$} & “G1” & $77.2 \pm 1.9$ & $64.8 \pm 2.9$ & $31.6 \pm 1.8$ & $32.84 \pm 1.3$ & $12.76 \pm 0.7$ \\
\hline & “G2” & $78 \pm 1.5$ & $63.8 \pm 1.9$ & $28 \pm 1.6^{\#}$ & $37.24 \pm 2^{\#}$ & $12.7 \pm 0.4$ \\
\hline & “G3” & $91.6 \pm 4.5^{\# \#}$ & $83.2 \pm 3.1^{\# \#}$ & $27.6 \pm 0.9^{\#}$ & $47.36 \pm 5^{\#}$ & $16.64 \pm 0.6^{\#}$ \\
\hline & “G4” & $84.4 \pm 2.3^{*}$ & $71 \pm 1.6^{*}$ & $33.4 \pm 0.54^{*}$ & $36.8 \pm 1.9^{*}$ & $14.2 \pm 0.3^{*}$ \\
\hline & “G5” & $77.8 \pm 1.9^{* *}$ & $61.8 \pm 1.9^{* *}$ & $32.6 \pm 1.07^{*}$ & $32.84 \pm 3.3^{*}$ & $12.36 \pm 0.4^{*}$ \\
\hline
\end{tabular}

Numerical data were expressed as mean \pm SD. Groups, fresh oil (G2) and frying oil (G3) groups are compared with normal control group (G1) and take $(*)$, meanwhile, hibiscus groups (G4) and (G5) are compared with $(\mathrm{G} 3)\left({ }^{*}\right)$, P value $<0.05$ considered significant. $\left({ }^{*}\right)$ indicating presence of significant difference between (G2 and G3) compared with normal control group (G1). $\left.{ }^{* *}\right)$ highly significant. ${ }^{* * *}$ ) very highly significant. (\#) indicating presence of significant difference between (G4 and G5) compared with (G3). (\#\#) highly significant. (\#\#\#) very highly significant.

Table 3. Effects of different treatments on liver functions in both liver tissue and serum of studied groups.

\begin{tabular}{|c|c|c|c|c|c|c|}
\hline & & $\begin{array}{l}\text { Total Protein } \\
\text { (mg/g) }\end{array}$ & $\begin{array}{c}\text { Albumin } \\
(\mathrm{mg} / \mathrm{g})\end{array}$ & $\begin{array}{l}\text { Total Bilirubin } \\
(\mathrm{mg} / \mathrm{g})\end{array}$ & AST (U/g) & $\operatorname{ALT}(\mathbf{U} / \mathbf{g})$ \\
\hline \multirow{5}{*}{$\begin{array}{l}\text { In Tissue } \\
(\mathrm{mg} / \mathrm{g}) \text { and } \\
(\mathrm{U} / \mathrm{g}) \\
\text { Groups }\end{array}$} & “G1" & $3.12 \pm 0.25$ & $1.89 \pm 0.2$ & $0.194 \pm 0.009$ & $92 \pm 6$ & $78 \pm 8$ \\
\hline & "G2" & $2.71 \pm 0.3^{\#}$ & $1.28 \pm 0.1^{\#}$ & $0.244 \pm 0.01^{\#}$ & $114 \pm 6^{\#}$ & $110 \pm 12^{\#}$ \\
\hline & “G3" & $2.27 \pm 0.15^{\# \#}$ & $1.09 \pm 0.15^{\# \#}$ & $0.496 \pm 0.012^{\# \#}$ & $183 \pm 13^{\# \# \#}$ & $166 \pm 11^{\# \# \#}$ \\
\hline & "G4" & $2.81 \pm 0.25^{*}$ & $1.43 \pm 0.2^{*}$ & $0.314 \pm 0.01^{*}$ & $136 \pm 8^{* *}$ & $115 \pm 7^{* *}$ \\
\hline & “G5” & $2.95 \pm 0.2^{* *}$ & $1.6 \pm 0.1^{* *}$ & $0.22 \pm 0.01^{* *}$ & $104 \pm 5^{* * *}$ & $94 \pm 10^{* * *}$ \\
\hline \multirow{5}{*}{$\begin{array}{l}\text { In Serum (g/ } \\
\mathrm{dl}) \text { and }(\mathrm{U} / \mathrm{dl}) \\
\text { Groups }\end{array}$} & "G1" & $6.46 \pm 0.05$ & $3.46 \pm 0.11$ & $0.302 \pm 0.008$ & $62 \pm 2$ & $63.4 \pm 2$ \\
\hline & “G2” & $6.58 \pm 0.08^{\#}$ & $3.46 \pm 0.05$ & $0.32 \pm 0.01^{\#}$ & $83 \pm 3.6^{\#}$ & $82.8 \pm 2^{\#}$ \\
\hline & “G3" & $6.34 \pm 0.05^{\#}$ & $3.36 \pm 0.1$ & $0.4 \pm 0.01^{\#}$ & $94.4 \pm 3^{\# \#}$ & $92 \pm 1.6^{\# \#}$ \\
\hline & "G4" & $6.8 \pm 0.12^{*}$ & $3.54 \pm 0.12^{*}$ & $0.38 \pm 0.008$ & $73 \pm 2.2^{* *}$ & $75 \pm 3^{* *}$ \\
\hline & “G5” & $6.66 \pm 0.11^{*}$ & $3.54 \pm 0.14^{*}$ & $0.3 \pm 0.008^{*}$ & $65 \pm 2.5^{* *}$ & $68 \pm 2.3^{* *}$ \\
\hline
\end{tabular}

Numerical data were expressed as mean \pm SD, Groups fresh oil (G2) and frying oil (G3) groups are compared with normal control group (G1) (\#), meanwhile, hibiscus groups (G4) and (G5) are compared with (G3) $\left({ }^{*}\right)$, P value $<0.05$ considered significant. $\left({ }^{*}\right)$ indicating presence of significant difference between (G2 and G3) compared with normal control group (G1). (**) highly significant. (***) very highly significant. (\#) indicating presence of significant difference between (G4 and G5) compared with (G3). (\#\#) highly significant. (\#\#\#) very highly significant.

"E" hibiscus groups, liver showing healthy showing normal portal area; note the normal bile duct, hepatic artery, and portal vein, (HE X400). (Score lesion: 0).

\section{Discussion}

Heating the cooking oils repeatedly causes a series of chemical reactions, including hydrolysis, polymerization, and isomerization, which leads to lipid peroxidation (Choe and Min, 2007). The acid value as well as the fatty acid value (oleic acid \%) in group G3 were both increased in the current analysis. This may be because lipid peroxidation produces a wide range of volatile and non-volatile elements, such as free fatty acids, alcohols, aldehydes, ketones, hydrocarbons, trans- isomers, cyclic and epoxy compounds, (Kaviyani et al., 2014; Zhang et al., 2012).

Also, when compared to control G2, the oil colour of both G3 and G4 was increased, particularly reddish. Chemical reactions increase foaming, darkening of oil colour, and increase viscosity when the same cooking oil is reused excessively. The peroxide value of oils can easily be increased by high temperatures, visible light, and oxygen.

In addition, peroxide value was increased according to repeated frying process, meanwhile, the effect of adding both irradiated and un-irradiated hibiscus powder to oil showed significant decreases. According to various studies, oils with a peroxide value greater than 9 meq $\mathrm{O}_{2} / \mathrm{kg}$ trigger negative health effects by rising reactive oxygen species and secondary lipid peroxidation products, 

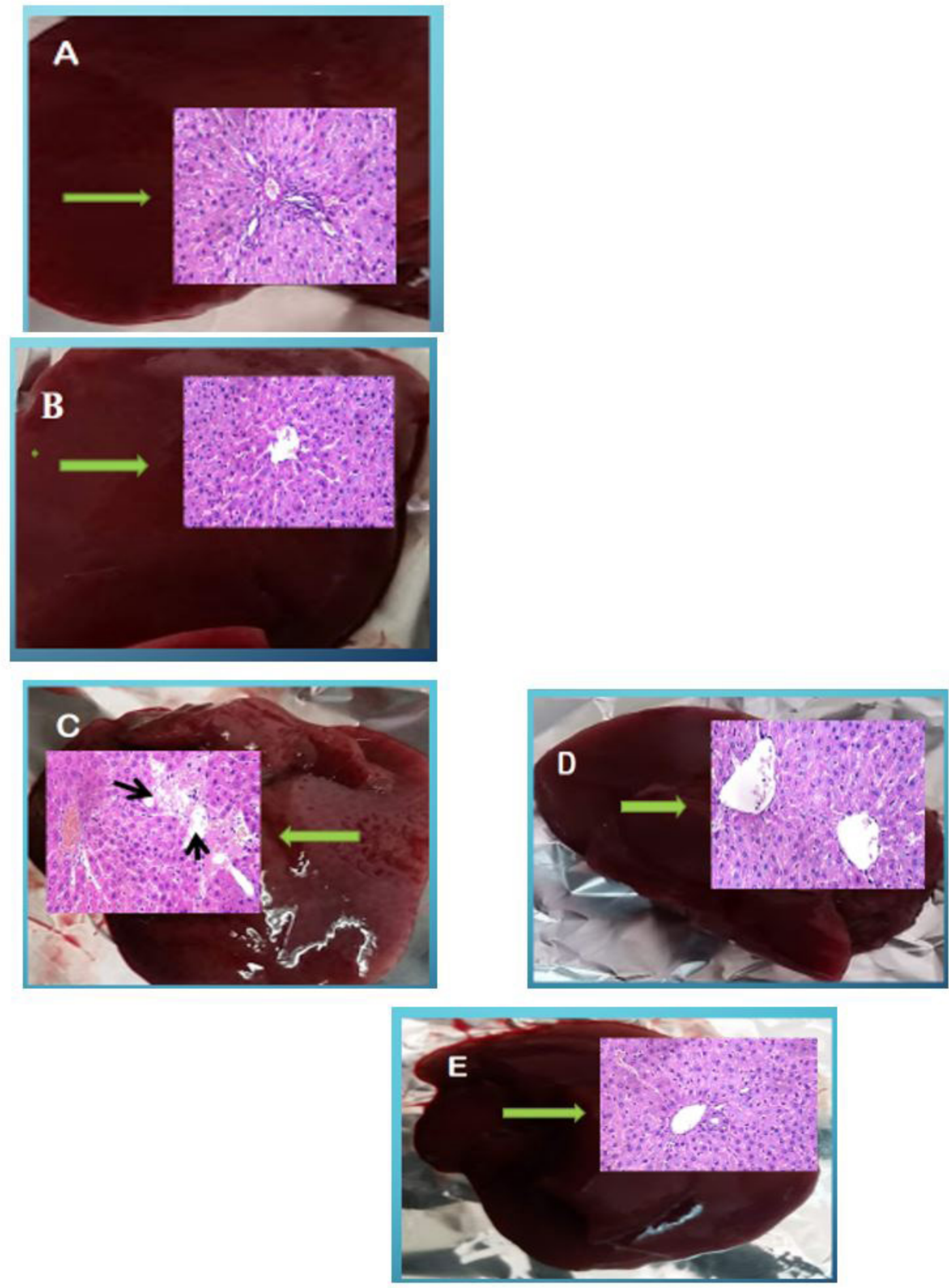

Figure 2. Showing both Macroscopic images and histological study of Liver samples from all studied groups, "A" normal group, and "B" from "G2", showing completely normal liver and normal hepatic parenchyma; note the normal central vein, hepatocytes, and blood sinusoids, while in "C", frying oil group"G3" showing fibrosis and congestion in the central vein (arrow head), Swelling degeneration of some hepatocytes (arrows) with focal areas of necrotic hepatocytes. Whereas, In both "D" as well as, "E" hibiscus groups, liver is completely normal and showing healthy and normal portal area; note the normal bile duct, hepatic artery, and portal vein, (HE X400) (Score lesion: 0 ). 
which promote cardiovascular and inflammatory diseases (Lobo et al., 2010).

Hydrogen abstraction from the active methylene group is used to oxidize polyunsaturated fatty acids, and the result is normally stabilized by a molecular rearrangement to form a conjugated diene (Antolovich et al., 2002). The conjugated dienes, as well as the peroxide value, are frequently used to classify the consistency of oils used in the food industry and to calculate primary oxidation products (Abuzaytoun and Shahidi, 2006).

Current results showed that, the conjugated dienes were higher in G3 compared to G4 and G5. Furthermore, G5 did not show any significant differences that might be due to increasing of antioxidant activity of irradiated hibiscus.

The ability of herbal extracts to inhibit the production of conjugated dienes determines their antioxidant function. These findings are consistent with Lee et al. (2013), who found that gamma irradiation of centipede grass resulted in plant pigment degradation while biological activities remained stable or increased Furthermore, Lee et al. (2012) discovered that gamma irradiation significantly increased Aloe vera antioxidant activity, which was accompanied by a colour change.

Flavonoids, anthocyanins, and phenolic compounds, for example, are known to act as radical scavengers in natural products (Chirag et al., 2014). Herbal extracts' antioxidant activity is generally described by their ability to reduce the formation of conjugated dienes when linoleic acid or methyl linoleate are used as substrates. Therefore, the presence of flavonoids, quercetin, and ascorbic acid in Hibiscus sabdariffa L. flowers may explain its antioxidative effects (Kumar and Singh, 2012).

Quercetin can protect unsaturated fatty acids from oxidation because it contains a phenolic hydroxyl group. The current study discovered quercetin to be an effective antioxidant with antioxidative properties and the ability to inhibit the formation of conjugated dienes.

These changes in the physicochemical properties of repeatedly frying oils which mentioned above, have harmful effects on lipid profile and liver functions. As, there are highly significant increases in lipid profile (cholesterol, triglyceride, LDL and VLDL) in the level of both liver tissue as well as serum in "G3", compared with "G1" and "G2". It may be due to, the ingestion of repeatedly frying oil, causes profound alteration in membrane composition fluidity and function. This alteration is most likely linked to a higher rate of cholesterol turnover, as shown by the increased cholesterol excretion. Increases in triglyceride levels after oil consumption may also be attributable to a rise in the supply of free fatty acid substrate for esterification (Aruna et al., 2004). Moreover according to Leong et al. (2010), in rats, intake of repeatedly heated vegetable oil has been shown to reduce NO levels significantly. Vegetable oil heating causes oxidative stress, resulting in NO sequestration and inactivation. In the presence of oxidised low-density lipoprotein cholesterol and oxidative stress, endothelial cells' capacity to release NO may be inhibited.

On the contrary, hibiscus groups "G4" and "G5" showed significant decreases in (cholesterol, triglyceride, LDL and VLDL) and increasing in HDL, compared with "G3". Several studies on hibiscus have found phenolic constituents, flavonoids, phytosterols, and polyphenols, all of which are believed to have antioxidant properties (Sanchez et al., 2003). Many studies have demonstrated the function of antioxidants in preventing various human diseases by preventing oxidative stress and harm in biological tissues (Repetto and Llesuy, 2002). Anthocyanins, which are present in hibscuse, were also reported to have several times more antioxidant activity than traditional antioxidants like ascorbate (Wang et al., 2000).

Anthocyanin, flavonols, glycosides, are well known potent free radical scavengers and also it was reported that the Hibiscus sabdariffa tend to reverse the change in lipid peroxidation activity, indicating decreased lipid peroxidation and damage to cells and tissues. Hence, the possible mechanism by which the Hibscuse decrease lipid peroxidation effect in ingestion reused frying oil condition could be attributed to the presence of natural antioxidants and its free radical scavenging properties (Ubani et al., 2011).

In addition, the current study showed that ingestion repeatedly frying oil has significant decreases in oxygen consumption of liver mitochondria in "G3" compared with "G1" and "G2". Meanwhile both "G3" and "G4" showed significant increases in oxygen consumption compared with "G3".The mitochondria are the only other subcellular structure aside from the nucleus to contain DNA. Histones, unlike nuclear DNA (nDNA), do not protect mitochondrial DNA (mtDNA) (Schmidt-Nielsen, 1984). Since mtDNA lacks the structural protection and repair mechanisms provided by histones, it is extremely vulnerable to damage. The most metabolically active cells, such as the liver, have the greatest number of mitochondria (Cohen and Gold, 2001). Mitochondria use roughly $90 \%$ of the oxygen used by the cell during the ATP production process (Chance et al., 1979). Mitochondrial proteins are impaired directly, which reduces their affinity for substrates or coenzymes and, as a result, their functions (Liu et al., 2002). In extreme cases, energy production deficiency can lead to liver failure, coma, and death (Fromenty and Pessayre, 1997).

In addition, when rats were given repeated doses of frying oil, their respiratory control was found to be poorer than in the control group. In rats with a high lipid profile, it could be attributed to a decrease in oxygen consumption, phosphorylation rate, and hepatic mitochondria respiratory function (Neustadt and Pieczenik, 2008; Weiss et al., 2012). Meanwhile, flavonoids, saponins, and polyphenols have been shown to increase antioxidant system activity and reduce nitric oxide output in the hypercholesterolemic rats.

Indeed, the current study showed defect of liver functions, which occurred in "G3", through elevated in liver enzymes and decreasing in protein levels compared with hibiscuse groups. This means that fried oil tends to raise both the ALT and AST levels. This is in agreement with the findings reported earlier (Shastry et al., 2011). The major release of these enzymes in the animals fed oxidized vegetable oil can be attributed to the degradation of liver cells and changes in membrane permeability. Whilst, hibiscuse antioxidant effect may reduce this oxidative, by a reduction of the liver endothelial cells harm.

The existence of natural antioxidants and its free radical scavenging properties may be the mechanism 
by which Hibscuse has a hepato-protective effect in a hyperammonemic state (Amin and Hamza, 2005; Odigie et al., 2003).

Overcome, irradiated hibiscus by gamma irradiation have a potential role against oxidative stress of repeatedly frying oil in both in vitro as well as in vivo studies more than hibiscus only, it may be related to Gamma irradiation which, increases total poly phenol content, the antioxidant and angiotensin converting enzyme (ACE) inhibitory activity, Polyphenols have been known to be responsible for the antioxidant activity of the products. Their free radical scavenging activity via electron donation to 2 , 2-Diphenyl-1-picrylhydrazyl radical (DPPH) radical, which, increasing its antioxidant activity (Mun'im et al., 2017).

In addition, a previous study found that increasing the gamma irradiation dose increased the antioxidant activity (Heidarieh et al., 2012). Increased antioxidant activity can also be induced by the fragmentation of the hydroxyl group in the sample, which enables hydrogen atoms to react with the free radical and turn it into a more stable substance (Shah et al., 2015). Furthermore, the highly antioxidant effects of irradiated hibiscus, may be due to the increment of total phenolic content and flavonoid under gamma irradiation which, could be due to the gamma irradiation-induced release of these compounds from their glycosidic forms, as well as the degradation of larger compounds into smaller compounds (Harrison and Were, 2007).

\section{Conclusions}

The data of current study clarify three basic points, first, (1) frequent use of frying edible oils, provides an opportunity to exist more noxious compounds as well as lipid peroxidation products in the cooking oils. Second, (2) the harmful effects that occur to the oil after repeatedly frying are not limited to the physicochemical characteristics of oils only, but also, reflected on alterations of liver mitochondria as well as liver functions and lipid profile after dietary intake of these thermally oxidized oils. Third, (3) the concept behind reusing this frying oil is to save money on food preparation, while ignoring the potential for adverse effects on human health. But by using both hibiscus as well as irradiated hibiscus against harmful effects of repeatedly frying oils may allow us in the coming years to overcome this harmful effects as well as taking into account the economic cost to the consumer.

\section{Acknowledgements}

This research work was supported by Prof. Dr. Sherein Saied Abdelgayed, Professor of pathology, faculty of veterinary medicine, Cairo university, Egypt. That has put her knowledge compendia open to me to bring the histopatholgical study of the current work in its present form.

\section{References}

ABUZAYTOUN, R. and SHAHIDI, F., 2006. Oxidative stability of flax and hemp oils. Journal of the American Oil Chemists' Society, vol. 83, no. 10, pp. 855-861. http://dx.doi.org/10.1007/s11746006-5037-7.

AMIN, A. and HAMZA, A.A., 2005. Hepatoprotective effects of Hibiscus, Rosmarinus and Salvia on azathioprine-induced toxicity in rats. Life Sciences, vol. 77, no. 3, pp. 266-278. http://dx.doi. org/10.1016/j.lfs.2004.09.048. PMid:15878355.

ANTOLOVICH, M., PRENZLER, P.D., PATSALIDES, E., MCDONALD, S. and ROBARDS, K., 2002. Methods for testing antioxidant activity. Analyst, vol. 127, no. 1, pp. 183-198. http://dx.doi.org/10.1039/ b009171p. PMid:11827390.

ARUNA, K., RUKKUMANI, R., SURESHVARMA, P. and MENON, V.P., 2004. Role of an aminothiazole derivative on ethonal and thermally oxidized sunflower oil - induced toxicity. Polish Journal of Pharmacology, vol. 56, no. 2, pp. 233-240. PMid:15156074.

ASSOCIATION OF OFFICIAL ANALYTICAL CHEMISTS - AOAC, 2005. Official methods of analysis. 18th ed. Maryland: AOAC.

CHANCE, B., SIES, H. and BOVERIS, A., 1979. Hydroperoxide metabolism in mammalian organs. Physiological Reviews, vol. 59, no. 3, pp. 527-605. http://dx.doi.org/10.1152/ physrev.1979.59.3.527. PMid:37532.

CHIRAG, P., TYAGI, S., HALLIGUDI, N. and YADAV, J., 2014. Antioxidant activity of herbal plants: a recent review. Journal of Drug Discovery and Therapeutics, vol. 8, pp. 1-8.

CHOE, E. and MIN, D.B., 2007. Chemistry of deep-fat frying oils. Journal of Food Science, vol. 72, no. 5, pp. R77-R86. http:// dx.doi.org/10.1111/j.1750-3841.2007.00352.x. PMid:17995742.

COHEN, B.H. and GOLD, D.R., 2001. Mitochondrial cytopathy in adults: what we know so far. Cleveland Clinic Journal of Medicine, vol. 68, no. 7, pp. 625-626, 629-642. http://dx.doi.org/10.3949/ ccjm.68.7.625. PMid:11453081.

CULLING, C.F.A., 1983. Handbook of histopathological and histochemical technique. 3rd ed. London: Butterworth, $214 \mathrm{p}$.

DHANDAPANI, S., SUBRAMANIAN, V.R., RAJAGOPAL, S. and NAMASIVAYAM, N., 2002. Hypolipdimic effect of Cuminum cyminum L. on alloxan-induced diabetic rats. Pharmacological Research, vol. 46, no. 3, pp. 251-255. http://dx.doi.org/10.1016/ S1043-6618(02)00131-7. PMid:12220968.

DIEFFENBACHER, A. and POCKLINGTON, W.D., 1987. Standard methods for the analysis of oils, fats and derivatives. 7th ed. Oxford: Blackwell Scientific.

DUNG, C.H., WU, S.C. and YEN, G.C., 2006. Genotoxicity and oxidative stress of the mutagenic compounds formed in fumes of heated soybean oil, sunflower oil, and lard. Toxicology In Vitro, vol. 20, no. 4, pp. 439-447. http://dx.doi.org/10.1016/j.tiv.2005.08.019. PMid:16216463.

EL-MELEIGY, S., 1989. Physiological studies on roselle plant Hibiscus sabdariffa L. Egypt: Ani Shams University, 124p. Ph. D. Thesis in shams university Cairo, Egypt.

FROMENTY, B. and PESSAYRE, D., 1997. Impaired mitochondrial function in microvesicular steatosis effects of drugs, ethanol, hormones and cytokines. Journal of Hepatology, vol. 26, suppl. 2, pp. 43-53. http://dx.doi.org/10.1016/S0168-8278(97)804965. PMid:9204409.

HARRISON, K. and WERE, L.M., 2007. Effect of gamma irradiation on total phenolic content yield and antioxidant capacity of Almond skin extracts. Food Chemistry, vol. 102, no. 3, pp. 932-937. http://dx.doi.org/10.1016/j.foodchem.2006.06.034.

HEIDARIEH, M., BORZOUEI, A., RAJABIFAR, S., ZIAIE, F. and SHAFIEI, S., 2012. Effects of gamma irradiation on antioxidant activity 
of Ergosan. Iranian Journal of Radiation Research, vol. 9, no. 4, pp. 245-249.

KALT, W., PRANGE, R.K. and LIDSTER, P.D., 1992. Postharvest color development of strawberries: influence of maturity, temperature and light. Canadian Journal of Plant Science, vol. 73, no. 2, pp. 541-548. http://dx.doi.org/10.4141/cjps93-074.

KAVIYANI, M., GHAZI, N.M., SHARIATI, M.A. and ATAROD, S., 2014. The study of frying oils properties. International Journal of Advanced Engineering Research and Technology, vol. 2, pp. 90-96.

KHOO, H.E., AZLAN, A., TANG, S.T. and LIM, S.M., 2017. Anthocyanidins and anthocyanins: colored pigments as food, pharmaceutical ingredients, and the potential health benefits. Food \& Nutrition Research, vol. 61, no. 1, 1361779. http://dx.doi.org/10.1080/16 546628.2017.1361779.

KU, S.K., RUHAIFI, M.S.M., FATIN, S.S., SAFFANA, M., ANNA, K.T., DAS, S. and KAMSIAH, J., 2014. The harmful effects of consumption of repeatedlyheated edible oils: a short review. La Clinica Terapeutica, vol. 165, no. 4, pp. 217-221. PMid:25203337.

KUMAR, A. and SINGH, A., 2012. Review on Hibiscus rosa sinensis. International Journal of Research in Pharmaceutical and Biomedical Sciences, vol. 3, no. 2, pp. 534-538.

LEE, E.M., BAI, H.W. and LEE, S.S., 2012. Gamma irradiation improves the antioxidant activity of Aloe vera (Aloe barbadensis Miller) extracts. Radiation Physics and Chemistry, vol. 81, no. 8, pp. 10291032. http://dx.doi.org/10.1016/j.radphyschem.2012.02.033.

LEE, E.M., LEE, S.S., BAI, H.W., CHO, J.-Y., KIM, T.H. and CHUNG, B.Y., 2013. Effect of gamma irradiation on the pigments and the biological activities of methanolic extracts from leaves of centipedegrass (Eremochloa ophiuroides Munro). Radiation Physics and Chemistry, vol. 91, pp. 108-113. http://dx.doi. org/10.1016/j.radphyschem.2013.06.010.

LEONG, X.F., MUSTAFA, M.R., DAS, S. and JAARIN, K., 2010. Association of elevated blood pressure and impaired vasorelaxation in experimental Sprague-Dawley rats fed with heated vegetable oil. Lipids in Health and Disease, vol. 9, no. 1, pp. 66. http://dx.doi. org/10.1186/1476-511X-9-66. PMid:20573259.

LEVESQUE, R., 2007. SpSS: programming and data management: a guide for SPSS and SAS users. 4th ed. Chicago: SPSS Inc.

LIU, J., KILLILEA, D.W. and AMES, B.N., 2002. Age-associated mitochondrial oxidative decay: improvement of carnitine acetyltransferase substrate-binding affinity and activity in brain by feeding old rats acetyl-L-carnitine and/or R-alpha-lipoic acid. Proceedings of the National Academy of Sciences of the United States of America, vol. 99, no. 4, pp. 1876-1881. http://dx.doi. org/10.1073/pnas.261709098. PMid:11854488.

LOBO, V., PATIL, A., PHATAK, A. and CHANDRA, N., 2010. Free radicals, antioxidants and functional foods: impact on human health. Pharmacognosy Reviews, vol. 4, no. 8, pp. 118-126. http://dx.doi. org/10.4103/0973-7847.70902. PMid:22228951.

MÉNDEZ, E., SANHUEZA, J., SPEISKY, H. and VALENZUELA, A., 1996. Validation of the Rancimat test for the assessment of the relative stability of fish oils. Journal of the American Oil Chemists' Society, vol. 73, no. 8, pp. 1033-1037. http://dx.doi. org/10.1007/BF02523412.

MUN'IM, A., RAMADHANI, F., CHAERANI, K., AMELIA, L. and ARRAHMAN, A., 2017. Effects of gamma irradiation on microbiological, phytochemical content, antioxidant activity and inhibition of Angiotensin Converting Enzyme (ACE) activity of Peperomia pellucida (L.) Kunth. Journal of Young Pharmacists, vol.9, no. 1s, pp. 65-69. http://dx.doi.org/10.5530/jyp.2017.1s.17.

MURPHY, T.W., 2012. Hepatic mitochondrial efficiency in lines of mice differing in feed intake. Lincoln: University of Nebraska, 71 p. M.S. Thesis in Science.
NEUSTADT, J. and PIECZENIK, S.R., 2008. Medication-induced mitochondrial damage and disease. Molecular Nutrition \& Food Research, vol. 52, no. 7, pp. 780-788. http://dx.doi.org/10.1002/ mnfr.200700075. PMid:18626887.

ODIGIE, I.P., ETTARH, R.P. and ADIGUN, S.A., 2003. Chronic administration of aqueous extract of Hibiscus sabdariffa attenuates hypertension and reverses cardiac hypertrophy in 2K-1 hypertensive rats. Journal of Ethnopharmacology, vol. 86, no. 2-3, pp. 181-185. http://dx.doi.org/10.1016/S03788741(03)00078-3. PMid:12738084.

POE, M., GUTFREUND, H. and ESTABROOK, R.W., 1967. Kinetic studies of temperature changes and oxygen uptake in a differential calorimeter: the heat of oxidation of NADH and succinate. Archives of Biochemistry and Biophysics, vol. 122, no. 1, pp. 204-211. http://dx.doi.org/10.1016/0003-9861(67)90140-3. PMid:4294746.

RAIFA, A.H., HEMMAT, K.I.K., HALA, M.S.E. and MERVAT, S.S., 2005. Increasing the active constituents of sepals of Roselle (Hibiscus subdariffa L.) plant applying gibberellic acid and benzyladenine. Journal of Applied Sciences Research, no. 2, pp. 137-146.

REPETTO, M.G. and LLESUY, S.F., 2002. Antioxidant properties of natural compounds used in popular medicine for gastric ulcers. Brazilian Journal of Medical and Biological Research, vol. 35, no. 5, pp. 523-534. http://dx.doi.org/10.1590/S0100879X2002000500003. PMid:12011936.

SÁNCHEZ, G., RODRÍGUEZ H, M.A., GIULIANI, A., NÚÑEZ SELLÉS, A.J., RODRÍGUEZ, N.P., LEÓN FERNÁNDEZ, O.S. and RE, L., 2003. Protective effect of Mangifera indica L. extract (Vimang®) on the injury associated with hepatic ischaemia reperfusion. Phytotherapy Research, vol. 17, no. 3, pp. 197-201. http://dx.doi. org/10.1002/ptr.921. PMid:12672145.

SCHERMER, S., 1967. The blood morphology of laboratory animals. London: Lengmans, Green and Co. Ltd., 350 p.

SCHMIDT-NIELSEN, K., 1984. Scaling, why is animal size so important? 1st ed. Cambridge: Cambridge University Press. http://dx.doi. org/10.1017/CBO9781139167826.

SECA, A.M.L., SILVA, A.M.S., SILVESTRE, A.J.D., CAVALEIRO, J.A., DOMINGUES, F.M. and PASCOAL-NETO, C., 2001a. Phenolic constituents from the core of kenaf (Hibiscus cannabinus). Phytochemistry, vol. 56, no. 7, pp. 759-767. http://dx.doi. org/10.1016/S0031-9422(00)00473-8. PMid:11314965.

SECA, A.M.L., SILVA, A.M.S., SILVESTRE, A.J.D., CAVALEIRO, J.A., DOMINGUES, F.M. and PASCOAL-NETO, C., 2001b. Lignanamides and other phenolic constituents from the bark of kenaf (Hibiscus cannabinus). Phytochemistry, vol. 58, no. 8, pp. 1219-1223. http:// dx.doi.org/10.1016/S0031-9422(01)00311-9. PMid:11738411.

SHAH, A., MASOODI, F.A., GANI, A. and ASHWAR, B.A., 2015. Effect of $\gamma$-irradiation on antioxidant and antiproliferative properties of oat $\beta$-glucan. Radiation Physics and Chemistry, vol. 117, pp. 120-127. http://dx.doi.org/10.1016/j.radphyschem.2015.06.022.

SHASTRY, C.S., AMBALAL, P.N., HIMANSHU, J. and ASWATHRANRAYANA, B.J., 2011. Evaluation of effect of reused edible oil on vital organs of Wistar rats. Journal of Health Science, vol. 1, no. 4, pp. 10-15.

SHIRWAIKAR, A., MALINI, S. and KUMARI, S.C., 2003. Protective effect of pongamia pinnata flowers against cisplatin and gentamicin induced nephrotoxicity in rats. Indian Journal of Experimental Biology, vol. 41, no. 1, pp. 58-62. PMid:15267137.

SORIANI, R.R., SATOMI, L.C. and PINTO, T.D.J.A., 2005. Effects of ionizing radiation in ginkgo and guarana. Radiation Physics and Chemistry, vol. 73, no. 4, pp. 239-242. http://dx.doi.org/10.1016/j. radphyschem.2005.01.003. 
SRIVASTAVA, S., SINGH, M., GEORGE, J., BHUI, K. and SHUKLA, Y., 2010b. Genotoxic and carcinogenic risks associated with the consumption of repeatedly boiled sunflower oil. Journal of Agricultural and Food Chemistry, vol. 58, no. 20, pp. 1117911186. http://dx.doi.org/10.1021/jf102651n. PMid:20886885.

SRIVASTAVA, S., SINGH, M., GEORGE, J., BHUI, K., MURARI SAXENA, A. and SHUKLA, Y., 2010a. Genotoxic and carcinogenic risks associated with the dietary consumption of repeatedly heated coconut oil. British Journal of Nutrition, vol. 104, no. 9, pp. 1343-1352. http://dx.doi.org/10.1017/S0007114510002229. PMid:20687968.

TANAKA, T., KOJIMA, T., KAWAMORI, N., YOSHIMI, N. and MORI, H., 1993. Chemoprevention of diethylnitrosamine-induced hepatocarcinogenesis by a simple phenolic acid protocatechuic acid in rats. Cancer Research, vol. 53, no. 12, pp. 2775-2779. PMid:8504418.

UBANI, C.S., JOSHUA, P.E. and ANIEKE, U.C., 2011. Effects of aqueous extract of Hibiscus sabdariffa L. calyces on liver marker enzymes of phenobarbitone-induced adult wistar albino rats. Journal of Chemical and Pharmaceutical Research, vol. 3, no. 4, pp. 528-537.

WANG, C.-J., WANG, J.-M., LIN, W.-L., CHU, C.-Y., CHOU, F.-P. and TSENG, T.-H., 2000. Protective effect of Hibiscus anthocyanins against tert- butyl hydro peroxide induced hepatic toxicity in rats. Food and Chemical Toxicology, vol. 38, no. 5, pp. 411-416. http:// dx.doi.org/10.1016/S0278-6915(00)00011-9. PMid:10762726.

WEISS, H., WESTER-ROSENLOEF, L., KOCH, C., KOCH, F., BALTRUSCH, S., TIEDGE, M. and IBRAHIM, S., 2012. The mitochondrial Atp8 mutation induces mitochondrial ROS generation, secretory dysfunction, and $\beta$-cell mass adaptation in conplastic B6-mt $\mathrm{t}^{\mathrm{FVB}}$ mice. Endocrinology, vol. 153, no. 10, pp. 4666-4676. http:// dx.doi.org/10.1210/en.2012-1296. PMid:22919063.

ZHANG, Q., SALEH, A.S., CHEN, J. and SHEN, Q., 2012. Chemical alterations taken place during deep-fat frying based on certain reaction products: a review. Chemistry and Physics of Lipids, vol. 165, no. 6, pp. 662-681. http://dx.doi.org/10.1016/j. chemphyslip.2012.07.002. PMid:22800882. 